\title{
Undesired Teacher Behaviours According to the Studentship Memories of Prospective Teachers in Primary School
}

\author{
Hüseyin Polat \\ Correspondence: Hüseyin Polat, Faculty of Education, Adıaman University, Adıyaman, 02040, Turkey
}

Received: July 22, 2015 Accepted: August 13, $2015 \quad$ Online Published: August 19, 2015

doi:10.11114/jets.v3i6.1044 URL: http://dx.doi.org/10.11114/jets.v3i6.1044

\begin{abstract}
The purpose of this study is to explore the types of undesired behaviours observed by prospective primary school teachers during their studentship at primary school. 35 voluntary prospective teachers studying at the faculty of education in Adiyaman University participated into the study, which was conducted within qualitative research techniques. According to their primary school memories of participants, teachers enacted mostly undesired behavioural patterns such as physical punishment, engaging in other works in lessons, insulting, threating and certain patterns of discrimination. Except engaging irrelevant subjects in lessons, the other undesired behavioural patterns are associated with reactions to students' behaviours such as making noise, taking other students' things without permission, grabbing, thievery, disobeying the classroom rules, running and rushing in the classroom, lying, misbehaving and complaining about other classmates. Additionally, according to the results of the study, the undesired behaviours which the prospective teachers never want to practice, when they become teachers, are mostly such behaviours of their teachers in primary school.
\end{abstract}

Keywords: primary school, teaching, professional job, undesired teacher behaviours

\section{Introduction}

While work or occupation could be defined as the service or product in return of which one takes money to make a living, professional job or profession could be defined as the service or product appearing as a result of performing specific standards with specific knowledge and abilities.

Teaching profession in Turkish legislation is defined as a specific expertise job, and a profession which requires an academic education and stipulates a preparation in special field education and general culture with pedagogical formation (Ministry of Education, 1973). In this sense, since 2006-2007 academic year, Institutions of Higher Education has been providing education for prospective teachers in three domains; "field and field education", "pedagogical content knowledge" and "general culture".

In many countries as well as Turkey, we could classify the proficiencies into six basic categories for prospective teachers who successfully fulfil the requirements of a-four-year teaching program including their probation and who succeed in specific lessons with satisfactory grades at the end or during the process (MEB, 2006; Barnes, 2005; Stephens \& Crawley, 1994; CCSSO, 2013):

1. Field Knowledge: program and its content, the subjects to teach, curriculum development.

2. Self-Knowledge: personal and professional values, professional learning and ethics application, career development

3. Knowledge of Students Identification: individual differences, students' development, determination of students' level.

4. Knowledge of Teaching-Learning Process: planning the teaching, practising the subject, practising the content, teaching strategies, learning environments, class management, teaching knowledge

5. Assessment: observing and assessing the development and teaching, recording the performances and evaluation.

6. Knowledge of School, Family and Society: leadership and cooperation, school, family and society affairs

Personal, academic development fields and proficiencies in teaching curriculum aim to constitute the required qualifications as a whole for those who will practice teaching as a profession.

Students graduating from various programs in high schools have to be in the same percentile in the university entrance 
exam in order to study in an undergraduate program designed for teacher training (http://osym.gov.tr/dosya/1-28470/h/tablo4.pdf). The candidates are expected to start their career assuming to have acquired the similar teaching skills through the training they received at undergraduate education lasting 4 years at least. The candidates are neither assessed for the job proficiency in terms of personal suitability nor required a final evaluation in this respect. Therefore, it is assumed that teaching programs make candidates acquire academic personal traits to succeed in teaching profession. This is the feature of some professional jobs especially being dominant by institutional aspects. Because institutional identities try to level down the contribution of personal features in practicing the profession. However, the teachers, who complete the undergraduate education at the same field and fulfilling the same requirement to create a professional class teacher, are observed to be described and graded with adjectives as "good", "successful", "ideal" and "effective" in literature. The characteristics determined for teachers are as follows: tolerant, patient, flexible, affectionate, understanding, humorous, encouraging, supportive, professional, cheerful, good ice-breaker, using time well, leader, complementary, connective, shaping, model, illuminating, facilitator, student counsellor, dutiful and self-confident, developing collaboration and cooperation in the class, knowing how, where and when to use his knowlede, successful in class management, class leader, benefiting from the questions effectively, having responsibility for the teachers and students he works with, interested in students' emotions and needs, striving to understand people correctly, confident to meet the expectations, respectful to students' personalities, taking the expectations and needs into consideration, open-minded and objective, innovative, understanding and commenting about social changes and having a high success expectations from the students (Erden,1998; Demirel, 1999; Kuğuoğlu, 2004; Kılıç et al., 2004; Açıkgöz, 2003; Çankırıl1, 2005; Celep, 2000; Çelik 2000; Akbulut, 1999; Yeşil, 2008; Can, 2004; Çelikten, Şanal and Yeni, 2005 ).

Characteristics of teachers determined in literature, which are mostly about the personal features, are expected to be acquired through general culture field lessons and pedagogical content knowledge in training programs. Averages of the courses of prospective teachers who finish the programs are as follows: in pre-school teaching program; from a total of 147 credits, $46.94 \%$ is allocated for field education, $27,21 \%$ to pedagogical content knowledge and $25.85 \%$ to general culture courses; in class teaching program: $52.56 \%$ out of 156 total credits is allocated to field education, $25 \%$ to pedagogical content knowledge and $22,44 \%$ to general culture courses; in social sciences education; from 158 total credits, $52.53 \%$ is allocated to field education, $27.22 \%$ to pedagogical content knowledge and $20.25 \%$ to general culture courses; in science education; from 153 total credits, $55.56 \%$ is allocated to field education, $24.84 \%$ pedagogical content knowledge and $19.61 \%$ to general culture courses; in elementary mathematics education program: from 146 total credits, $47.95 \%$ is allocated to field education, $27.40 \%$ pedagogical content knowledge and $24.66 \%$ general culture courses; in Turkish Language teaching: from 145 total credits the allocation is as $53.10 \%$ to field education, $24.14 \%$ pedagogical content knowledge and $22.76 \%$ to general culture courses.

When we compare the allocation of the courses in teaching programs with the qualifications a teacher should have, we can notice that the candidates take lessons between $46-53 \%$ for teaching proficiency in their fields, whereas they take lessons between 24-27\% for self-knowledge, knowledge of students' identification, knowledge of teaching or learning process, assessment, information about school, family and society and they take lessons between 19-23\% in general culture lessons.

It is concluded that the prospective teachers find pedagogical content knowledge courses as the most important ones in their fields according to the studies carried out in Turkey (Eroğlu, 2012; Taşkın \& Haciömeroğlu, 2010; Çetin, 2009; Süral, 2015; Yüksel, 2009; Yalçın \& Şengül-Avşar, 2014).

When teaching is compared with other professional jobs such as architecture, engineering and medicine, it could be assumed that another qualification field should exist for teaching profession because the word teacher alone is not adequate to define the job but certain specific adjectives are needed to describe it such as good, successful, ideal and effective. This qualification can be defined as aesthetics or art. These new terms are based on the belief that teaching profession requires some qualifications that could be either innate or taught in life. This could also mean that the personal characteristics play a role more in teaching profession than any other professional jobs.

In some studies, the description (K1lıç, 2014) about the teachers whose perceptions of profession are above the average level, having lots of qualifications and perfect artistic point of views are so exaggerated that they are thought to be impossible to coexist in any single teacher. Besides, a teacher, who is described with subjective degrees as good, successful, ideal and effective, cannot achieve the same success in educating and teaching.

The researches aiming to decipher the codes of successful teachers often focused on teachers' behaviours that reflect their personal characteristics (Demirel, 1999; Erden, 1998; Küçükahmet, 2002; Kuğuoğlu, 2004; Kılıç et al., 2004; Yörükoğlu, 2008; Açıkgöz, 2003; Çankırılı, 2005; Celep, 2000; Çelik 2000; Akbulut, 1999; Yeşil, 2008; Can, 2004).

Behaviour is any activity performed by an organism that can be observed by another organism or an instrument. 
(Atkinson, R. L., \& Atkinson, R.C., Smith, E.E., BEM, D.J., Nolen-Hoeksema, S., 2008). In the light of the definition above, a teacher behaviour can be defined as any action performed any teacher that can be observed in and out of the teaching environment by any person related with teaching process. Some typical teacher behaviours could be exampled as decent, dignified, balanced, being understood by pupils correctly, flexible and tolerant, providing a class management without physical or verbal punishment, good, understanding, patient, lovely, interested, like parents and a good ice-breaker (Yörükoğlu, 2008; Ubuz \& Sarı, 2009; Genç, 2007).

The factors that make teachers' behaviours important are their reflection in pupils mind. Küçükahmet (2002) describes different teacher types; one type of teachers encourages collaboration among students with love and respect, another teacher character creates abduction among students with fear and anxiety, a democratic-connective teacher is regarded as friendly, patient, outgoing, tender, good-tempered, and lovely by students and an autocratic-dominative teacher is described as anti-social, spiteful, hostile, egoist, arrogant, ill-tempered, impatient and stubborn with harsh behaviours.

The factors that affect teachers' behaviours (Özkaya, 2013) could be stated as follows; teachers' faith, teaching profession and proficiency, teachers' attitudes towards teaching profession, teachers' awareness and teachers' reflections. For Korthagen, although a teacher has a perfect capability, his faith, intuitions, intentions and the environment he lives in create some serious restrictions (2004).

Social psychologists believe that attitudes improve and form as a result of cognitive, emotional and behavioural experiences in general (Atkinson \& Atkinson et al., 2008). After all, teachers' attitudes and contribute to create the students' own attitudes and shape their behaviours. It could be said that there is a cause and effect relation between teachers' behaviours - attitudes and students' behaviours - attitudes.

A teacher who has an expectation that students will show a favourable behaviour pattern in academic field and a teacher who has an important role for students in acquiring positive attitudes (Yontar,2007; Aslan \& Yalçın,2013) should avoid the humiliating attitudes, insulting and degrading words against the students before his/her classmates (Yörükoğlu, 2008:81). Since students exist with all their feelings in the class and participate in the lessons, do activities and are in contact with their peers and teachers with these feelings, students' attitudes towards their teachers, lessons, school and other variables affect their learning life in future (Semerci \& Semerci, 2004:139).

As teachers' behaviours have a significant role in teaching-learning process and development of personality, the present paper aims at studying undesired teacher behaviours recalled by prospective class teachers experienced during their primary education. In accordance with this objective, depending on the opinions of prospective teachers, an effort was made to find out the information about the teacher candidates' memories with their primary school teachers, the type of behaviours that their teachers did not desire in the classroom, how their teachers reacted when they encountered with an undesired behaviour in the classroom, the frequencies the candidates encountered with undesired behaviours of their teachers' during their primary school education and types of these behaviours, which of their primary school teachers' behaviours they found incorrect with experiences they currently have, the type and form of the undesired behaviour their teachers practiced to one of their friends at least and what types of behaviours they will definitely avoid in their teaching career.

The period we wanted the participants to recall goes 7-9 years back. This makes us think that a memory a candidate share with us probably influenced him significantly.

\section{Method}

The population of the study consists of prospective teachers studying in the first and second grades in the department of Primary Education in the faculty of education in Adiyaman University in 2011-2012 education year. The sample is 35 voluntary prospective teachers who want to participate in the research. The demographic distribution of candidates participating in the study is shown in table 1.

Table 1. The Demographic Distribution of the Sample

\begin{tabular}{|c|c|c|c|}
\hline & & $\mathrm{f}$ & $\%$ \\
\hline \multirow[t]{2}{*}{ Gender } & Female & 26 & 74 \\
\hline & Male & 9 & 26 \\
\hline \multirow[t]{6}{*}{ Age } & 17 & 2 & 5.71 \\
\hline & 18 & 12 & 34.26 \\
\hline & 19 & 12 & 34.26 \\
\hline & 20 & 7 & 20 \\
\hline & 21 & 1 & 2.85 \\
\hline & 22 & 1 & 2.85 \\
\hline
\end{tabular}

According to Table $1,74 \%$ of the sample is females and $26 \%$ of it is males. $34.26 \%$ of the sample is 18 and 19 years old, $20 \%$ is 20 years, $5.71 \%$ is 17 years, $2.85 \%$ is 21 and 22 years old. 
In this study, qualitative survey and semi-structured interview techniques were used. The purpose of using this survey and technique is to obtain profound information from the interviewee. With this purpose a semi-structured interview form, titled "opinions of prospective teachers about undesired behaviours of their teachers", was developed and used.

There were 9 questions in the instrument. The participants were given an interview form and required to think about their memories with their teachers in primary school period and to write their memories on the forms.

The data obtained from the study was evaluated within content analysis method in which a text could be summarized with smaller sub-categories with codes depending on certain rules in a systematic and iterable technique (Büyüköztürk, Çakmak, Akgün, Karadeniz, \& Demirel, 2012:240). Through this technique, it was intended to reach the concepts and relations that could explain undesired teachers' behaviours in the primary school memories of candidates. In the analysis of data, the processes were as follows; coding data, finding themes, arranging themes and codes, identifying the findings and commenting (Yıldırım \& Şimşek, 2008). 7 questions in our data collection tool were accepted as the main themes. In accordance with our intention of the study, data were presented in frequencies and percentages in tables.

\section{Findings}

Table 2. Memories of Classroom Prospective teachers

\begin{tabular}{|c|c|c|c|}
\hline & & $\mathrm{f}$ & $\%$ \\
\hline \multirow[t]{2}{*}{ Memory type } & Positive & 16 & 45.71 \\
\hline & Negative & 13 & 37.14 \\
\hline \multirow[t]{5}{*}{ Undesired Behaviour } & Physical Punishment & 8 & 26.38 \\
\hline & Insult & 1 & 2.85 \\
\hline & Threat & 1 & 2.85 \\
\hline & Busy with other things & 2 & 5.71 \\
\hline & Discrimination & 1 & 2.85 \\
\hline \multirow[t]{4}{*}{ The reason explained of undesired behaviour } & Noise & 3 & 8.57 \\
\hline & Taking a friend's thing without permission & 1 & 2.85 \\
\hline & Being late to the class & 1 & 2.85 \\
\hline & Academic failure & 1 & 2.85 \\
\hline \multirow[t]{2}{*}{ The lesson to which the memory belongs } & Mathematics & 2 & 5.71 \\
\hline & Social Sciences & 1 & 2.85 \\
\hline \multirow[t]{6}{*}{ The behaviour appreciated } & A Special Interest & 6 & 17.14 \\
\hline & Unexpected Positive Attitude & 1 & 2.85 \\
\hline & Helping (financial) & 2 & 5.71 \\
\hline & Reading Book & 1 & 2.85 \\
\hline & Reward & 3 & 8.57 \\
\hline & Others & 3 & 8.57 \\
\hline Those who don't mention any memories & & 6 & 17.14 \\
\hline
\end{tabular}

According to Table 2, $45.71 \%$ of participants had favourable memories of primary school education period, while $37.14 \%$ of the participants had negative memories. Among the undesired teachers' behaviours within these memories, 26.38\% contained physical punishment, $5.71 \%$ the engagement other things during the lessons and $2.85 \%$ insult, threat and discrimination. According to the remarks of prospective teachers, the reasons of undesired behaviours resulted from noise with $8.57 \%$ followed by taking a friend's thing without permission, coming late to the lesson and academic failure with $2.85 \%$.

In a research, studying is democratic teacher, conducted with the students in the faculty of education in Gazi University, the behaviours of a democratic teacher were determined as avoiding using assessment as means of discipline and not beating any student (Küçükahmet, 2002:17). 
Table 3. Unfavourable Students' Behaviours that Class Teachers Unapproved according to Prospective Teachers

\begin{tabular}{|c|c|c|}
\hline & f & $\%$ \\
\hline Making noise & 9 & 25.71 \\
\hline Talking without permission / standing up & 10 & 28.57 \\
\hline Fighting & 4 & 11.43 \\
\hline Damaging the school materials & 2 & 5.71 \\
\hline Damaging friends' materials & 1 & 2.85 \\
\hline Being late to the lesson & 3 & 8.57 \\
\hline Not getting ready for the lesson & 2 & 5.71 \\
\hline Coming to lessons without studying (Academical) & 3 & 8.57 \\
\hline Engaging with other things during lessons & 13 & 37.14 \\
\hline Talking to friends during lessons & 16 & 45.71 \\
\hline Joking with each other during lessons & 1 & 2.85 \\
\hline Not doing homework & 9 & 25.71 \\
\hline Absence & 1 & 2.85 \\
\hline Swearing & 2 & 5.71 \\
\hline Asking permission for loo & 1 & 2.85 \\
\hline Not standing up when teacher gets into the class & 1 & 2.85 \\
\hline Disturbing classmates & 3 & 8.57 \\
\hline Littering the classroom & 2 & 5.71 \\
\hline Disrespecting friends & 1 & 2.85 \\
\hline Disrespecting teachers & 1 & 2.85 \\
\hline Stealing & 1 & 2.85 \\
\hline Disobeying class instructions & 1 & 2.85 \\
\hline Running in the classroom & 1 & 2.85 \\
\hline Lying & 1 & 2.85 \\
\hline Naughtiness & 1 & 2.85 \\
\hline Complaining about classmates & 1 & 2.85 \\
\hline
\end{tabular}

As seen in Table 3, students' behaviours that classroom teachers do not accept are determined as speaking with friends during lessons $45.71 \%$, engaging with other things during lessons $37.14 \%$, speaking without permission / standing up $28.57 \%$, making noise and not doing homework $25.71 \%$, fighting $11.43 \%$, being late to the lesson, coming to lessons without studying and disturbing friends $8.57 \%$, not getting ready for the lesson, swearing in the class and littering the classroom $5.71 \%$, damaging friends' materials, joking with each other during lessons, absence, asking permission for loo, not standing up when teacher gets into the classroom, disrespecting friends, disrespecting teachers, stealing, disobeying classroom instructions, running in the classroom, lying, naughtiness and complaining about friends $2.85 \%$.

In his study, Danaoğlu (2009) revealed that undesired students' behaviours that teachers encountered mostly are talking to each other, talking without permission and interrupting the teaching process deliberately. In another study, undesired behaviours that teachers encountered mostly were said to be not ready when the bell rings, indifference to questions asked, the content taught and coming late to the class (Sezgin \& Duran, 2010). From the findings of these studies, it could be understood that undesired behaviours are virtually similar.

Table 4. The Reaction of Classroom teachers to undesired behaviours according to Prospective teachers

\begin{tabular}{lcc}
\hline & f & $\%$ \\
\hline Warning & 11 & 31.43 \\
Physical punishment & 21 & 60 \\
Insult & 3 & 8.57 \\
Threat & 3 & 8.57 \\
Scolding & 3 & 8.57 \\
Embarrassing & 1 & 2.85 \\
Punishment & 8 & 22.86 \\
Sending off & 1 & 2.85 \\
Changing the seating & 2 & 5.71 \\
Exhorting & 3 & 8.57 \\
Ignoring & 3 & 2.85 \\
\hline According to Table 4, when
\end{tabular}

According to Table 4, when class teachers encountered with an unapproved student behaviour responded with physical punishment $60 \%$, warning $31.43 \%$, punishment (out of beating) $22.86 \%$, insulting, threating, scolding and exhorting $8.57 \%$, changing the seating $5.57 \%$ and embarrassing and ignoring $2.85 \%$. These findings confirm the results of Mursal's study (2005) about teachers' behaviours which caused $5^{\text {th }}$ grade students to show unfavourable behaviours. However, in another study, as reply to the question what the teacher had to do when he entered the classroom and saw the pupils rushing around and not ready for the lesson, $80 \%$ of the pupils did not approve physical intervention against them (Ergün \& Duman, 2000)

Several studies about teachers' qualifications revealed that although prospective teachers could communicate with 
people comfortably and regard themselves adequate in human relations, they believed the education they underwent was insufficient (Arslan \& Özpınar, 2008), and it is concluded that being an effective teacher required being a model with his behaviours to the society and students, morally justified, know students in all aspects, affectionate (Şahin, 2011), and prospective teachers were observed to stipulate existence social attributions such as understanding human nature, honesty, leadership and respect in an ideal class teacher.

Table 5. Disturbing Behaviours of Class teachers in Educational Process Experienced by Prospective Teacher

\begin{tabular}{llcc}
\hline & \multicolumn{1}{c}{$\%$} & $\mathrm{f}$ & $\%$ \\
\hline Disturbing Behaviours of Class Teachers & Yes & 26 & 74.29 \\
& No & 9 & 25.71 \\
\hline
\end{tabular}

According to table 5 , prospective teachers pointed out that $74.29 \%$ of classroom teachers showed disturbing behaviours and the rest $25.71 \%$ did not experience any disturbing behaviours.

Table 6. The Type of Disturbing Behaviours of Classroom Teachers Experienced by Prospective Teachers

\begin{tabular}{lcc}
\hline & $\mathrm{f}$ & \multicolumn{1}{c}{} \\
\hline Forcing to go to the blackboard & 1 & 2.85 \\
Physical Punishment & 12 & 34.26 \\
Not exhibiting the students' works in the class & 1 & 2.85 \\
Angry manners & 2 & 5.71 \\
Repression & 2 & 5.71 \\
Insulting & 4 & 11.43 \\
Scolding & 2 & 5.71 \\
Discrimination & 1 & 2.85 \\
Drinking beverages and eating food in the lesson & 2 & 5.71 \\
Academic Inadequacy & 4 & 11.43 \\
Ignoring & 2 & 5.71 \\
\hline
\end{tabular}

According to Table 6, prospective teachers determined the types of the disturbing behaviours of class teachers as follows: $34.26 \%$ physical punishment, $11.43 \%$ insulting and academic inadequacy, $5.71 \%$ angry manners, repression and scolding, $2.85 \%$ leaving students' works out of exhibitions in the classroom, forcing to go to the board and discrimination.

In a study, it was determined that there is a high correlation between teachers' behaviours and learning outcomes (Korthagen, 2004). When this finding is compared with the ones in table 6, undesired teacher behaviours may result in negative learning outcomes. We can see that it is highly possible to encounter with negative learning results caused by undesired teachers' behaviours.

Table 7. Unapproved Class Teachers' Behaviours According to Prospective Class Teachers

\begin{tabular}{lcc}
\hline & $\mathrm{f}$ & $\%$ \\
\hline Physical Punishment & 18 & 51.43 \\
Insulting & 12 & 34.26 \\
Scolding & 1 & 2.85 \\
Discrimination & 11 & 31.43 \\
Ignoring & 5 & 14.29 \\
Engaging with other things in the class & 1 & 2.85 \\
Threating & 2 & 5.71 \\
Angry Manners & 7 & 20 \\
Exaggerated Tolerance & 5.71 \\
Academic Inadequacy & 2 & 20 \\
Forcing to read books & 7 & 1 \\
\hline
\end{tabular}

According to Table 7, prospective teachers determined the reaction to mistaken behaviours as follows: $51.43 \%$ physical punishment, $34.26 \%$ insulting, 31.43\% discrimination, $20 \%$ angry attitudes and academic inadequacy, $14.29 \%$ neglecting, $5.71 \%$ threating and being excessive tolerance, $2.85 \%$ scolding, engaging with other things in the class and forcing to reading book.

A study by Dilekmen (2001) showed that the first ranks in negative behaviours of class teachers are physical punishment with $27.32 \%$ and uttering insulting and provoking words with $24.59 \%$.

Another study revealed that there are many factors affecting teachers' behaviours in classroom and especially the ones experiencing exhaustion tend to bring their exhaustion mood into classes, direct this negative mood to the students, thus, create an unfavourable class atmosphere while they practice teaching (Cemaloğlu \& Kayabaş1, 2007). 
Table 8. Disturbing Behaviour of Classroom Teachers to at least one of the Friends of Prospective Teachers.

\begin{tabular}{|c|c|c|c|}
\hline & & $\mathrm{f}$ & $\%$ \\
\hline \multirow{3}{*}{$\begin{array}{l}\text { Did your classroom teacher behave in a disturbing way to at least one } \\
\text { of your friends? }\end{array}$} & Yes & 23 & 65.71 \\
\hline & No & 10 & 28.57 \\
\hline & Unanswered & 2 & 5.71 \\
\hline
\end{tabular}

According to table $8,65.71 \%$ of prospective teachers stated their class teachers behaved to at least one of their friends in a disturbing way while $28.57 \%$ of them did not witness anything of this kind and $5.7 \%$ of them left the question unanswered.

Table 9. The Types of Disturbing Behaviours of Class Teachers to at least one of the Friends of Prospective Teachers in the Educational Process

\begin{tabular}{lcc}
\hline & $\mathrm{f}$ & $\%$ \\
\hline Forcing to go to the board & 1 & 2.85 \\
Physical Punishment & 14 & 40 \\
Threating & 1 & 2.85 \\
Angry Manners & 3 & 8.57 \\
Insulting & 8 & 22.86 \\
Discrimination & 2 & 5.71 \\
\hline
\end{tabular}

According to Table 9, prospective teachers determined the type of the disturbing behaviours of class teachers as follows: $40 \%$ physical punishment, $22.86 \%$ insulting, $8.57 \%$ angry manners, $5.71 \%$ discrimination and $2.85 \%$ forcing to go to the board and threatening.

Table 10. Behaviours Which Prospective Class Teacher will definitely Avoid as Teachers

\begin{tabular}{|c|c|c|}
\hline Behaviours to be avoided by prospective class teachers & f & $\%$ \\
\hline Physical Punishment & 28 & 80 \\
\hline Threatening & 1 & 2.85 \\
\hline Angry Manners & 9 & 25.71 \\
\hline Repression & 4 & 11.43 \\
\hline Insulting & 14 & 40 \\
\hline Discrimination & 3 & 8.57 \\
\hline Unfair or Rough Punishment & 1 & 2.85 \\
\hline Academic Inadequacy & 2 & 5.71 \\
\hline Shouting & 4 & 11.43 \\
\hline Exaggerated Tolerance & 1 & 2.85 \\
\hline
\end{tabular}

According to table 10, the behaviours mentioned to be avoided by prospective teachers are respectively: $80 \%$ physical punishment, $40 \%$ insulting, $25.71 \%$ angry manners, $11.43 \%$ repression and shouting, $8.57 \%$ discrimination, $5.71 \%$ academic inadequacy, $2.85 \%$ threatening, unfair or rough punishment and exaggerated tolerance. These findings also confirmed the types of behaviours which disturbed prospective teachers during their primary education (see Table 7). It can be inferred that prospective teachers do not wish to apply such types of behaviours that disturbed them in their school years to their students.

\section{Conclusion and Discussion}

In this study, behaviour types which were not approved by prospective teachers of primary education department of faculty of education were examined in the light of their primary education period experiences. $45.71 \%$ of prospective teachers made positive comments while 37.14 of them had unfavourable memories. Undesired behaviour types, also survived as unpleasant experiences in their memories, are physical punishment ranking first (23.53\%), being busy with irrelevant subjects, insulting, threatening and discrimination respectively. This finding confirmed the findings of other studies about strategies preferred by teachers as reaction to undesired student behaviours (Sarıtaş, 2006; Dilekmen, 2001). However, in certain other studies, in order to cope with undesired student behaviours, individual dialoguing, verbal warning, reminding the rules, contacting with parents, going towards the student's desk, asking questions in order to engage the student, saying the student's name to attract his attention and engaging the student with the content by attracting his attention were suggested to deploy as means (Çankaya and Çanakç1, 2011; Sezgin and Duran, 2010; Güleç and Alkış, 2004). When the reactions stated by the pupils to undesired pupils' behaviours with the reaction stated by the teachers themselves, we generally see differences rather than similarities. Thus, it is obvious that comparative researches dealing with undesired teachers' behaviours and the strategies they implement to cope with undesired students' behaviours are needed to be conducted.

According to prospective class teachers, reasons for unfavorable class teacher behaviors were noise, grabbing 
classmates' things, stealing, disobeying class rules, rushing in the classroom, naughtiness, lying, complaining about friends. These findings confirm with studies with the same objectives (Çetin,2013; Keleş 2010; Gürşimşek ve Saygıll, 2008; Dönmez ve Cömert, 2009; Yüksel 2006; Özer 2009; Balay ve Sağlam, 2008; Sadık, 2006; Özdemir,2009). In the sudies, unapproved students' behaviors mostly share similarities whereas the strategies to cope with these behaviors differ to some extent.

Reaction by class teachers against unapproved students behaviors were usually as physical punishment, warning, punishment out of physical punishment, scolding, threating, verbal punishment, changing the seating, embarrassing, sending off and directing the interest. The studies dealing with the strategies to cope with unfavorable students' behaviors support these findings with various ranking in frequencies (Çankaya, 2011; Kılıç-Özmen, 2009; Özer, 2009; Beşdok, 2007; Tolunay 2008).

Mocking at students, comparing them with each other, inconsistency in class management, discrimination, rudeness, making use of punishment as means of discipline, being uninterested are regarded to result in unapproved students' behaviors both by teachers and students (Mursal, 2005). That is, unapproved teachers' behaviors foster unapproved students' behaviors and, the strategies to cope with unapproved students behaviors usually ignite their recurrence.

In the study, prospective teachers generally stated that they experienced disturbing teacher behaviours during their school years. They sorted them out as such: physical punishment, insulting, reprimanding, academic inadequacy, angry manners, repression, ignorance, (teacher's) consuming of food and beverage, not displaying the works, forcing them to go to the blackboard and discrimination.

According to the findings, prospective teachers sorted out unfavourable behaviours of their primary school teachers as such: physical punishment, insulting, discrimination, angry manners, academic inadequacy, ignoring, threatening, exaggerated tolerance, forcing them to read books, reprimanding and being busy with other subjects during classes. In the light of this data, unfavourable teacher behaviours that prospective teachers experienced their primary school years are similar to teacher behaviours that they accept as wrong. $65.71 \%$ of prospective teachers participated in this study stated that their primary school teachers exhibited disturbing behaviours to his/her friend once at least while $28.57 \%$ of them have expressed that they were never subjected to an kind of undesired behaviour from their teachers. Participant with unfavourable memories stated that these disturbing behaviours included physical punishment $(40 \%)$, insulting (22.86\%), angry manners $(8.57 \%)$, discrimination $(5.71 \%)$, threatening $(2.85 \%)$ and forcing them to go to the board (2.85\%). In their study Kılıç and Özmen $(2009 ; 190)$, observed that the higher emotional intelligence the teachers had, the less they faced with undesired student behaviours. Nonetheless, a recent research conducted on teachers, doctors and engineers, teachers scored the lowest levels of emotional intelligence and job satisfaction (Turgut, 2014).

Özdemir (2009:139) also found a weak positive and significant relation between undesired student and emotional burnout, depersonalisation and personal failure experienced. The same study has also suggested that the more undesired students' behaviours the teachers experienced, the more emotional burnout, depersonalisation and personal failure they faced.

In our study, prospective teachers sorted out the behaviours they will avoid as teachers as such: physical punishment $(80 \%)$, insulting $(40 \%)$, angry manners $(25.71 \%)$, repression $(11.43 \%)$, shouting $(11.43 \%)$, discrimination $(8.57 \%)$, academic inadequacy $(5.71 \%)$, excessive tolerance $(2.85 \%)$ and unfair or rough punishment $(2.85 \%)$. These findings showed the consistency between the unfavourable class teachers' behaviours and the unapproved class teachers' behaviours and the prospective class teachers were aware of the behaviours that they will avoid in teaching. However, a study conducted by Sarıtaş suggested that prospective teachers that did not take class management courses tended to make use of punishment and authority more in order to prevent undesired student behaviours and, preferred to cope with each problem individually rather than creating class rules and a class management policy.

In conclusion, prospective teachers stated that unapproved class teacher behaviours exercised by their teachers during their primary education are physical punishment, teacher's engagement in other subjects, insulting, threatening and discrimination. They also expressed that when their teachers faced with undesired behaviours, they mostly used physical punishment, warning, punishment, insulting, threatening, reprimanding, explaining, change their seating, embarrassing and caring respectively. Undesired behaviour types of teachers which prospective teachers experienced during their school years are significantly similar with the behaviour types which they were determined to avoid applying in their teaching practices.

\section{Suggestions}

During the study, it was observed that prospective teachers had unpleasant memories and comments about their teachers in their primary education. In early childhood period and primary education years, emotional and social developments of students are of more importance than their academic success and physical development. Therefore, pre-school 
teachers and primary school teachers ought not to apply physical punishment, insulting, threatening, discrimination and being uninterested in students as these behaviour types tend to hamper emotional and social developments of students. It is suggested the courses in pre-school and primary education dealing with personality development, social and emotional development be increased in number and improved in quality along with positive class management courses.

In higher education, prospective teachers should take tests assessing personality, emotional and social development along with field tests at the beginning, during and at the end of undergraduate education respectively.

\section{References}

Arslan, S., \& Özpınar, İ. (2008). Teachers Qualifications: Comparison between Primary School Curriculum Expectations and Teachers Acquisitions in Education Faculties. Necatibey Faculty of Education Electronic Journal of Science and Mathematics Education, 38-63.

Aslan, S., \& Yalçın, M. (2013). The Prediction of Attitudes towards Teaching Profession. Through Five Factor Personality Dimensions. Journal of National Education, 169-178.

Atkinson, R. L., Atkinson, R. C., Smith, E. E., BEM, D. J., \& Nolen-Hoeksema, S.(2008). Introduction to Psychology ( $4^{\text {th }}$ ed.). Ankara: Arkadaş Publishing.

Balay, R., \& Sağlam, M., (2005). The Opinions of Teachers Concerning the Negative Behaviours in Class. Yüzüncü Yıl University Journal of Faculty of Education, 5(2), 1-24.

Barnes, D. (2005). The Significance of Teachers' Frames for Teaching. T. Russell, \& H. Munby, Teachers and Teaching (pp. 18-19). London: The Falmer Press.

Beşdok, D. (2007). Assessment of Capability for Preventing Undesired Student Behaviours Which High School Teachers Confront in Classroom Management. (Unpublished Master's Thesis). Selcuk University Social Sciences Institute. Konya.

Can, N. (2004). Development of Teachers and Effective Teacher Behaviours. Erciyes University Journal of Institute of Social Sciences, 103-119.

Cemaloğlu, N., \& Kayabaşı, Y. (2007). The Relationship between the Burnout Level of Teachers Classroom Management and Discipline Models. Journal of Gazi Education Faculty, 123-155.

Çankaya, İ., \& Çanakçı, H. (2011) Undesirable Student Behaviours That Primary School Teachers Confront and Coping Strategies for These Behaviours. Turkish Studies-International Periodical for the Languages, Literature and History of Turkish or Turkic, 6(2), Spring, 307-316

Çelikten, M., Şanal, M., \& Yeni, Y. (2005). Teaching Profession and Its Properties. Erciyes University Journal of Institute of Social Sciences, 207-237.

Çetin, Ş. (2001). A Research on Ideal Teacher. Journal of National Education, 19-21.

Çetin, F. (2009). Attitudes of the Students of the Faculty of Education towards Teaching Profession Knowledge Courses. The Journal of Industrial Arts Education Faculty of Gazi University, 58-64

Danaoğlu, G. (2009). Student' Misbehaviours and Investigating Tackling Strategies of Primary Teachers and Branch Teachers In Fifth Classes of Primary Education (Unpublished Master's thesis). Çukurova University Institute of Social Sciences Department of Primary Education.

Dilekmen, M. (2001). In-class Behaviours of Primary School Teachers. Journal of Modern Education, 31-36.

Dönmez, B. \& Cömert, M. (2009). Prospective Teachers' and Practice Teacher's Perceptions about Capabilities in Coping with Undesired Student Behaviours in Class. Ahi Evran University Journal of Faculty of Education, 10(2), 47-55.

Ergün, M., \& Duman, T. (2000). Teacher Behaviours in Critical Cases. Retrieved from http://www.egitim.aku.tr/ertayip1.htm on October 17, 2014

Genç, S. Z. (2007). The Peculiarities Which an Ideal Academician should Possess throughout the Views of the Students. Journal of National Education, 210-218.

Güleç, S., Alkış, S. (2004). The Strategies Implemented by Teachers in Changing Behaviors. Uludă Üniversitesi Eğitim Fakültesi Dergisi, 12(2), 247-266

Gürşimşek, I., \& Saygılı, G. (2008) Student' Perceptions Concerning with Misbehaviours in Classroom. Dokuz Eylül University Buca Faculty of Education Journal, 23, 152-159.

Keleş, Z. (2010). Undesired Behaviour Problems that $1^{\text {st }}$ Class Teachers Face in the Classroom Management and the 
Methods They Cope with (Unpublished Master's Thesis). Yeditepe University Institute of Social Sciences, Istanbul

Kılıç, A. Ç. (2014). School Culture as a Predictor of Teacher Professionalism. Education and Science, 105-118.

Kılıç, A., \& Acat, M. B. (2007). Necessity and Operational Level of the Courses in Teacher Training Programs According to Prospective Teachers' Perceptions. Manas Journal of Social Studies, 21-38.

Kılıç-Özmen, Z. (2009). Relationship between Emotional Intelligence Levels of Primary Teachers and Comprehending Undesired Student Behaviours and the Methods They Cope with (Unpublished Master's Thesis). Marmara University Institute of Educational Sciences.

Korthagen, F. A. (2004). In Search of the Essence of a Good Teacher: Towards a More Holistic Approach in Teacher Education. Teaching and Teacher Education, 77-97. http://dx.doi.org/10.1016/j.tate.2003.10.002

Küçükahmet, L. (2002). Teaching as a Profession: Introduction to Teaching Profession. Ankara: Nobel Publishing.

Learning Progression for Teachers (2013).

www.ccsso.org/Documents/2013/2013_INTASC_Learning_Progression_For_Teachers.pdf

MEB (2006). General Qualifications for Teaching Profession. Retrieved from meb.gov.tr: otmg.meb.gov.tr/YetGenel.html on October 28, 2014

Mursal, E. (2005). Teacher and Student Views about Teacher Behaviours Resulting in Undesired Student Behaviours of $1^{\text {st }}$ Level $5^{\text {th }}$ Class in Primary Schools (Unpublished Master's Thesis). Abant Izzet Baysal University Institute of Social Sciences Department of Primary Education.

OSYM (2015). Field students of higher education degree programs with central placement. http://osym.gov.tr/dosya/1-28470/h/tablo4.pdf

Özdemir, T. (2009) Relationship between Frequency of Undesired Student Behaviours and Burnout Level of Teachers (Unpublished Master's Thesis). Abant Izzet Baysal University Institute of Social Sciences Department of Educational Sciences Educational Administration and Supervision Program

Özer, G. (2009). Views about Undesirable Behaviours Faced by Prospective Teachers in Classroom Environment and Coping Strategies with These Behaviours (Unpublished Master's Thesis). Bülent Ecevit University Institute of Social Sciences.

Özkaya, M. (2013). Teacher Behaviours in the Light of Literature. EKEV Academic Review, 399-408.

Sadık, F. (2006). Undesirable Student Behaviours and Analysing of Dealing Strategies According to Teacher, Student and Parent Views and Effect on Teachers' Dealing Strategies of the Education Program Based on Assertive Discipline Model (Unpublished Master's Thesis). Çukurova University Institute of Social Sciences Department of Educational Sciences.

Sarıtaş, M. (2006). Strategies Used to Change and Rehabilitate Undesired Student Behaviours in Classroom in the Light of Prospective Teachers' Assessments. Uludağ University Journal of Faculty of Education, XIX (1), 167-187.

Semerci, N., \& Semerci, Ç. (2004). Attitudes of Teachers in Turkey. Firat University Journal of Social Sciences, 137-146.

Sezgin, F., \& Duman, E. (2010). Prevention and Intervention Strategies of Primary School Teachers for the Misbehaviors of Students. Gazi University Journal of Gazi Education Faculty, 30(1), 147-168.

Stephens, P., \& Crawley, T. (1994). Becoming an Effective Teacher. United Kingdom: Nelson Thornes.

Şahin, A. (2011). Effective Teacher's Attitudes According to Teacher's Perceptions. Ahi Evran University Journal of Kirşehir Education Faculty, 239-259.

Süral, S. (2015). Prospective Class Teachers' Views about Necessity of Courses in Class Teaching Curriculum and Their Practicality Levels. Trakya University Faculty of Education Journal, 5, 34-43.

Taşkın, Ç. Ş., \& Hacı̈̈meroğlu, G. (2010). Importance of Pedagogy Courses on Preservice Teachers' Professional Development. Pamukkale University Journal of Education, N. 28(II), 165-174.

Tekışık, H. H. (2003). Personality Qualifications of Teacher. Training Teacher in the Modern Education Systems National Symposium (pp. 168-175). Ankara: Tekışık Publishing.

Tolunay, A. (2008). Undesired Student Behaviours Faced by Primary School Teachers in Classroom and Coping Methods with These Behaviours (Unpublished Master's Thesis). Uludağ University Institute of Social Sciences.

Turgut, G. (2014). Comparison of Perceived Social Support's and Emotional Intelligence Level's Effect on Job 
Satisfaction in Terms of Three Different Occupations: Engineer, Doctor and Teacher (Unpublished Master's Thesis). Maltepe University Institute of Social Sciences Department of Psychology Industrial and Organizational Psychology Program.

Ubuz, B., \& Sarı, S. (2009). Primary Teachers Candidates' Views on Good Teacher. Ondokuz Mayls University Faculty of Education Journal, 53-61.

Yalçın, S., \& Şengül- Avşar, A. (2014). Scaling Pedagogy Courses Faculty of Education with Rank-Order Judgments. Journal of Measurement and Evaluation in Education and Psychology, 5(2), 79-90.

Yıldırım, A., \& Şimşek, H. (2008). Qualitative Research Methods in Social Sciences. Ankara: Seçkin Publishing.

Yontar, A. (2007). An Investigation of the Primary School $5^{\text {th }}$ Grade Teachers' and Students' Point of Views in Terms of Punishment in Responsibility Training (Unpublished Master's Thesis). Çukurova University Institute of Social Sciences.

Yörükoğlu, A. (2008). Child’s Mental Health. Istanbul: Özgür Publishing.

Yüksel, A. (2006). Teacher Observations and Views on Undesired Student Behaviours in $1^{\text {st }}$, $2^{\text {nd }}$ and $3^{\text {rd }}$ Grades of $1^{\text {st }}$ Level in Primary Education (Unpublished Master's Thesis). Afyon Kocatepe University Institute of Social Sciences.

Yüksel, S. (2009). Views of Faculty of Education Students about Teaching Profession Knowledge Courses, Ankara University Faculty of Educational Sciences Journal, 42(1), 435-455. 